\title{
Awareness about bone marrow cancer in postgraduate students
}

\author{
Imran Qadir* and Aleena Ahmad Somroo
}

Qadir I, Somroo AA. Awareness about bone marrow cancer in postgraduate students. J Phlebol Lymphol. 2018;11(1):25-27.

Bone marrow is spongy tissues which have stem cells that can further develop in any type of blood cells which is very important to maintain our cellular functioning bone marrow cancer occurs when tumors are formed in the bones and this tumor can divide aggressively and can also spread to other parts of body. Questionnaire was developed consisting of 15

\section{INTRODUCTION}

Bone marrow is a spongy tissue which is present in the center of some bones e.g. hips and thighbones. As we know the bone marrow contains stem cells have the potential to develop into many types of blood cells which are red cells white blood cells and platelets. Bone marrow cancer occurs when a tumor is formed between bone this tumor can have the potential to show excessive growth which can lead to bone marrow cancer and it can also spread in other parts of body causing abnormality and diseases. Some of the common bone cancers are multiple myeloma, osteosarcoma, chondrosarcoma, Ewing's sarcoma. These are known as primary bone cancer. Although, bone cancers are rare. Bone marrow treatment can be done through chemotherapy, stem cell transplant and radiation administration. The basic purpose of this study was to determine the awareness of postgraduate student about this disease.

\section{METHODOLOGY}

Questionnaire was developed to check the awareness of students about "BONE MARROW CANCER". 37 students were selected from Bahauddin Zakariya University, inclusion criteria were that they were master of philosophy students and the exclusion criteria was that they were not the students of bachelor science.

\section{DISCUSSION AND RESULTS}

Multiple myeloma occurs less frequently in male and female, geographically, the frequency of the world population affected from this cancer is unevenly distributed which indicated that more people in the industrial region of Europe, New Zealand, Australia, and North America have more frequent risk of developing myeloma cancer. Occurrence and molarity seems to be stable in Asian countries and it is estimated to increase gradually over the coming years among the whites in western regions and black in the United States of America. The reason for increasing rate of this disease in the western countries is unknown [1].

Experiments done in previous study [2] demonstrated that in reaction to long term Helicobacter pylori infection, the cell which is derived from bone marrow can have the potential to continue living and generate the surface membrane of gastric and can take part in the dysplasia, metaplasia and malignant cancer. Illustration of diseased cancer advancement of the questions to determine the awareness about bone marrow cancer in postgraduate university student 37 M.Phil. students were selected. The basic purpose of this study was to know awareness about bone marrow cancer. It was concluded that only a few students were well aware of bone marrow cancer

Key Words: Bone marrow; Cancer; Questionnaire; Awareness; M.Phil Students.

bone marrow derived cell establishing of long term inflammation can serve as a model to study the epithelial cancer (Table 1).

Table 1: Questionnaire to check the awareness among students.

Bone marrow cancer is a Yes No
1. Viral disease
2. Bacterial disease
3. Fungal disease
4. Genetic disease

5. Metabolic disease

Ever suffered from bone marrow cancer

1. You

2. Your family

3. Your relative

4. Your neighbor

5. Your friend

Bone marrow cancer is transmitted by

1. Contacts or blood transfusion

2. From parents to offspring

Bone marrow cancer may be treated by

1. Medicines

2. Surgery

3. Do not worry, it is easily curable

According to questionnaire Table 2 which was about the etiology of bone marrow cancer, $45 \%$ of students agreed that bone marrow cancer is a viral disease while the rest of the $56 \%$ denied that it was a viral disease on the other hand $14 \%$ out of 37 agreed that bone marrow cancer was a bacterial disease while $86 \%$ did not agree on this. In the third question it was asked

Institute of Molecular Biology and Biotechnology, Bahauddin Zakariya University, Multan, Pakistan

${ }^{*}$ Correspondence: Dr. Imran Qadir, Institute of Molecular Biology and Biotechnology, Bahauddin Zakariya University, Multan, Pakistan, E-mail. mrimranqadir@hotmail.com ; Doi: 10.14303/1983-8905.1000054

Received: March 28, 2018, Accepted: May 1, 2018, Published: May 7, 2018

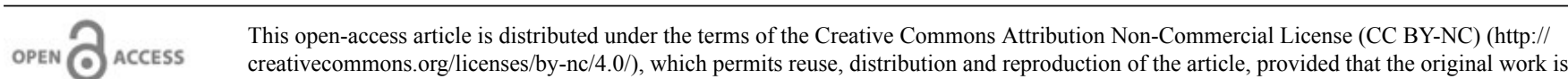
properly cited and the reuse is restricted to noncommercial purposes. For commercial reuse, contact reprints@pulsus.com 
that what you think about bone marrow cancer as a fungal disease $8 \%$ said yes and $91 \%$ of the students said no. In the 4 th question $95 \%$ said yes to the bone marrow cancer as a genetic disease and $5 \%$ of them denied that it was not a genetic disease.

In the last question of Table 2, students were asked what you think about bone marrow as a metabolic disease $72 \%$ said Yes, rest of the $27 \%$ out of 37 student said No.

Table 2: Questionnaire to evaluate awareness about etiology of bone marrow cancer.

\begin{tabular}{lcc}
\hline Bone marrow cancer is a: & Yes & No \\
Viral disease & 0.45 & 0.56 \\
Bacterial disease & 0.14 & 0.86 \\
Fungal disease & 0.08 & 0.91 \\
Genetic disease & 0.95 & 0.05 \\
Metabolic disease & 0.72 & 0.27 \\
\hline
\end{tabular}

Table 3: Questionnaire to evaluate views about prevalence of bone marrow cancer.

\begin{tabular}{lll}
\hline Ever suffered from bone marrow cancer & Yes & No \\
You & 0 & 1 \\
Your family & 0.02 & 0.97 \\
Your relative & 0.02 & 0.97 \\
Your neighbor & 0.05 & 0.94 \\
Your friend & 0 & 1 \\
\hline
\end{tabular}

The Table 3, which was about the prevalence of bone marrow cancer $0 \%$ said that we suffer from bone marrow while $100 \%$ said that we did not suffer from this cancer, it was also asked that someone from your family did suffer from this cancer $2 \%$ said yes and $97 \% / 37$ said no. in the third question of Table 3, $2 \%$ agreed that someone from their relatives suffered from bone marrow cancer and $97 \%$ said no In the $2^{\text {nd }}$ last question it was asked that did someone from your neighbors suffered $5 \%$ said yes and $94 \%$ said no and in the last question $0 \%$ of the student said yes that their friend suffered from bone marrow cancer while $100 \%$ said no.

Table 4: Questionnaire to evaluate views about transmission of bone marrow cancer.

\begin{tabular}{lll}
\hline Bone marrow cancer is transmitted by & Yes & No \\
Contacts or blood transfusion & 0.32 & 0.65 \\
From parents to offspring & 0.68 & 0.32 \\
\hline
\end{tabular}

Table 5: Questionnaire to evaluate views about Hope for bone marrow cancer.

\begin{tabular}{lcc}
\hline Bone marrow cancer may be treated by & Yes & No \\
Medicines & 0.81 & 0.19 \\
Surgery & 0.67 & 0.32 \\
Do not worry, it is easily curable & 0.05 & 0.94 \\
\hline
\end{tabular}

In Table 4 students were asked about their views on the transmission of bone marrow cancer $32 \%$ out of 37 students agreed while the rest of $65 \%$ denied that this cancer is transmitted by blood contact, $68 \%$ of students think that bone marrow cancer is inherited while $32 \%$ of them did not think that it was passed on from parents to offspring.

Table 6: Awareness about etiology of bone marrow cancer: Views of M.Phil. students.

\begin{tabular}{|c|c|c|c|c|c|c|}
\hline \multirow[b]{2}{*}{ Questions } & \multicolumn{2}{|l|}{ Male } & \multicolumn{2}{|c|}{ Female } & \multicolumn{2}{|l|}{ Total } \\
\hline & Yes & No & Yes & No & Yes & No \\
\hline Viral disease & 0 & 1 & 0.53 & 0.62 & 0.45 & 0.56 \\
\hline Bacterial disease & 0 & 1 & 0.16 & 0.84 & 0.14 & 0.86 \\
\hline Fungal disease & 0 & 1 & 0.1 & 0.9 & 0.08 & 0.91 \\
\hline Genetic disease & 1 & 0 & 0.43 & 0.06 & 0.95 & 0.05 \\
\hline Metabolic disease & 0.2 & 0.8 & 0.9 & 0.18 & 0.72 & 0.27 \\
\hline You & 0 & 1 & 0 & 1 & 0 & 1 \\
\hline Your family & 0 & 1 & 0 & 1 & 0.02 & 0.97 \\
\hline Relatives & 0 & 1 & 0.03 & 0.96 & 0.02 & 0.97 \\
\hline Neighbor's & 0 & 1 & 0.06 & 0.93 & 0.05 & 0.94 \\
\hline Friend & 0 & 1 & 0 & 1 & 0 & 1 \\
\hline Parent to off spring & 0 & 1 & 0.37 & 0.62 & 0.32 & 0.65 \\
\hline Blood transformation & 0.2 & 0.8 & 0.78 & 0.25 & 0.68 & 0.32 \\
\hline Cure by medicine & 1 & 0 & 0.9 & 0.19 & 0.81 & 0.19 \\
\hline Surgery & 0.8 & 0.2 & 0.63 & 0.34 & 0.67 & 0.32 \\
\hline Easily curable & 0 & 1 & 0.06 & 0.94 & 0.05 & 0.94 \\
\hline
\end{tabular}

In Table 5 students were asked about the hope of treating the bone marrow cancer $81 \%$ student said yes that the bone marrow cancer may be treated with the medicines while $19 \%$ did not agreed in the $2^{\text {nd }}$ second question students said $67 \%$ yes to the fact of bone marrow treatment by surgery on the other hand $32 \%$ said no In the third and last question it was asked that what do you think about bone marrow is easily curable or not $5 \%$ out of 37 said yes and $94 \%$ said no.

Table 6 was about the etiology of bone marrow cancer consisting of 15 questions according to the view of male and female (gender biased). $100 \%$ of male out of 5 said yes that bone marrow is a viral disease, $100 \%$ of the male out of 5 said no that it is not a bacterial disease or fungal disease while $100 \%$ of male $43 \%$ of female said yes that the bone marrow cancer is a bacterial disease $80 \%$ of male said that bone marrow was not a metabolic disease while $90 \%$ of female said yes that it is a metabolic disease $100 \%$ of male do not agree that none of their neighbor, friend, relatives, family were ever effected by bone marrow cancer . $100 \%$ of male disagree that bone is transmitted from parents to off spring while $62 \%$ of female out of 32 also said no, $80 \%$ of male denied that bone marrow cancer was transmitted through blood contact while $78 \%$ of female think that it is transmitted through blood transfusion, $100 \%$ of male and $90 \%$ of female think that bone marrow can be cured by medicine. $80 \%$ of male views about the cure of bone marrow cancer by surgery is possible while $63 \%$ of female agreed on it too. While $100 \%$ of male out of 5 think that bone marrow is not easily curable while $94 \%$ of female do not think that bone marrow cancer is easily curable.

\section{CONCLUSION}

This study was done to determine the awareness about bone marrow cancer in M.Phil. Students from Bahauudin Zakariya University hence it is concluded that most of students were somewhat aware of this cancerous disease while the rest of them were not aware because they lack knowledge related to bone marrow cancer. 


\section{REFERENCES}

1. Becker N. Epidemiology of Multiple Myeloma. In T. Moehler \& H Goldschmidt (Eds.), Multiple Myeloma. Berlin, Heidelberg: Springer Berlin Heidelberg 2011;pp. 25-35.
2. Houghton J, Stoicov C, Nomura S, et al. Gastric cancer originating from bone marrow-derived cells. Science. 2004;306:1568-71. 